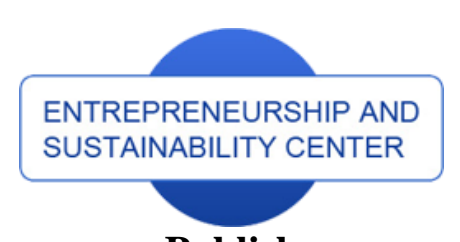

Publisher

http://jssidoi.org/esc/home enterprise

europe

network

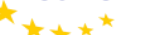

Business Support on Your Doorstep

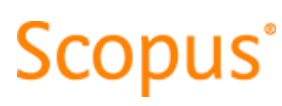

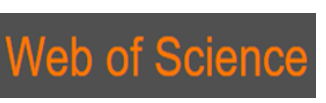

1 Clarivate

\title{
SECTORAL INTEGRATION AND INVESTMENT DIVERSIFICATION OPPORTUNITIES: EVIDENCE FROM COLOMBO STOCK EXCHANGE
}

\author{
Awais Ahmed ${ }^{1}$, Rizwan Ali ${ }^{2}$, Abdullah Ejaz², Muhammad Ishfaq Ahmad ${ }^{3}$ \\ 1, 2, 3 Lahore Business School, The University of Lahore, 1-KM Defence Road, \\ Lahore, Pakistan \\ E-mails: ${ }^{1}$ awais.ahmed@lbs.uol.edu.pk; ${ }^{2}$ rizwan.ali@lbs.uol.edu.pk; ${ }^{2}$ abdullah.ejaz@lbs.uol.edu.pk; \\ 3muhammad.ishfaq@lbs.uol.edu.pk
}

Received 25 October 2017; accepted 14 February 2018; published 30 March 2018

\begin{abstract}
This study examined the diversification opportunities within sectors of Colombo Stock Exchange by measuring co-integration among sectors. Those sectors of CSE which are not integrated with others offer good diversification opportunities. Moreover, the study also applies Granger Causality Test to determine which sectors of CSE cause other sectors. This helps an investor informing a diversified portfolio. This study employed daily closing indices of all sectors listed in Colombo Stock Exchange during the period from 1-12-2003 to 31-8-2016. Multivariate Co-integration and Pairwise Co-integration Tests are applied to determine integration among sectors and Granger Causality to determine causal relation among these Sectors of CSE. Stationarity by unit root test revealed that the fourteen sectors are selected for running cointgeration at Level 1 . Findings examined that no sector is integrated with other sectors. Thus, CSE provides excellent diversification opportunity to the investors. From an investor point of view, the findings of the study are helpful for a well-diversified portfolio by selecting stocks from those sectors which are not integrated with other sectors and minimize the unsystematic risk. This study significantly contribute the existing literature particularly those investors who want to diversify their portfolios domestically rather internationally.
\end{abstract}

Keywords: sectoral integration; diversification, portfolio; investment choice; Colombo Stock Exchange

Reference to this paper should be made as follows: Ahmed, A.; Ali, R.; Ejaz, A.; Ahmad, M. I. 2018. Sectoral integration and investment diversification opportunities: evidence from Colombo Stock Exchange, Entrepreneurship and Sustainability Issues 5(3): $514-527$. https://doi.org/10.9770/jesi.2018.5.3(8)

JEL Classifications: F36, G11 


\section{Introduction}

Modern Portfolio Theory Harry Markowitz's (1952) is an important landmark in Finance that changed the dynamics of Portfolio Formation. He introduced the concept of correlation among securities and argued that while forming a Portfolio, those securities should be selected that are negatively correlated with each other. This helps in reducing the unsystematic risk of an investor. Following MPT, investors began to diversify their portfolios. Initially, they diversified their portfolios in the domestic context. Later, the concept for formation of globally diversified portfolios began. (Levy \& Sarnat, 1970) and (Grubel \& Fadner, 1971) argued that investing in capital markets of other countries provided good diversification opportunities. Globalization, emergence of multinational companies and electronic trading of stocks increased cross border investments.

The discussion of measuring the integration began in 1980's. This trend increased in 1990's with the evolution of emerging markets. With such increased cross border investment, the financial markets of the world became integrated and diversification opportunities across stock markets of other countries began to decline. Especially after Asian Crisis of 1997, Terrorist attacks in US in 2001, US Subprime Mortgage Crisis of 2007 and Chinese Stock Market Turbulence of 2015, it was observed that shocks in one market were quickly transferred to other markets. The recent trend in literature has been towards seeking diversification opportunities among different sectors within a stock market. Studies conducted by Karim (2005), Wang et al., (2005), Al-Fayoumi et al., (2009), Ahmed (2012) and Mohammad Athar Noor et al., (2014) have explored the diversification opportunities across sectors of Malaysian, Chinese, Jordanian, Egyptian and Indian stock markets respectively and found that benefits of diversification can be reaped by forming a portfolio across sectors of a stock market.

The purpose of this study is to identify diversification opportunities across various sectors of Colombo Stock Exchange, Sri Lanka. Colombo Stock Exchange has emerged as an important regional market. After the end of the Sri Lankan Civil War on May 2009, CSE indexes increased rapidly creating new records. CSE was among the best performing stock exchanges in the world in 2009 as it jumped 125.2 percent during that year. The findings of the study will help investors to diversify their portfolios locally across various sectors of Sri Lankan stock market. The results of the study significantly and practically contribute to existing knowledge of Sri Lankan stock market and helpful for that investor who only want to trade within CSE market rather to move or invest other markets.

\section{Literature Review}

(Darbar \& Deb, 1997) documented that prompt globalization, increased financial reforms and rapid expansion in information and technology have almost removed all the hurdles in financial transaction among many financial stock markets. They have also established strong links among different stock markets in financial fraternity, therefore, interdependence of a domestic stock market on the foreign stock market has become of prime importance which led to a lot of research in this regard. In author's view that many stock markets in ASEAN and Asian NIC regions have been termed as emerging stock markets and these emerging stock markets have been very successful in attracting the attention of foreign investors. This increased interest has prompted many authors to carry out research in the stock markets of these two regions, however, research thrust got higher particularly after the Asian currency crisis (Huang \& Yang, 2000) and Daly (2003). Fewer studies have been written that examined the relationship of sectors within a stock market. (Grubel \& Fadner, 1971) and Karim (2005) have also highlighted this issue.

There are numerous literature have been written on different topics in the context of interdependencies of stock markets. For instance, (Chung \& Liu, 1994), Shamsuddin and Kim (2003), (Phaylaktis \& Ravazzolo, 2005), carried out studies on the theme of short term and long term interdependences of different stock markets. Similarly, (Arshanapalli \& Doukas, 1993), (Ghosh et al., 1999), (Masih \& Masih, 2002) wrote papers on leaders and followers on the particular set of stock markets. Soydemir (2000), (AuYong et al., 2004), and Chung (2005) also examined the market volatility transmission mechanism on the stock market of different countries. One of the most important contributions of the above mentioned 


\section{The International Journal \\ ENTREPRENEURSHIP AND SUSTAINABILITY ISSUES}

ISSN 2345-0282 (online) http://jssidoi.org/jesi/

2018 Volume 5 Number 3 (March)

http://doi.org/10.9770/jesi.2018.5.3(8)

studies were the exposition of diversification potential among several financial and capital stock markets. In the early literature of stock markets integration Grubel (1968), (Levy \& Sarnat, 1970), Solnik (1974) and Lessard (1976) documented that correlations between indices of foreign stock markets and domestic stock markets are low which give opportunities to investors to lower the risk without endangering the expected return of the portfolio by extending the portfolio's investment into foreign stocks.

(Odier \& Solnik, 1993; Longin \& Solnik 1995; Olienyk et al., 2002 and Glezakos et al., 2007) empirically proved that fruits of portfolio diversification lessen or may vanish completely when markets behave bearishly because co-movements among global capital markets have been increased due to the strong interdependence of economies across the globe. In the past three decades, 1987 Wall Street crisis, 1997 Asian Financial Crisis and 2008 mortgage crisis have shown the spillover effects among stock markets across the globe. These crises have only cemented the fact that returns from portfolio diversification become low or disappear in the time of crisis or markets behave bearishly. (Arshanapalli \& Doukas 1993; Sheng \& Tu, 2000; Izquierdo \& Lafuente, 2004; and Bekeart et al., 2005) examined the constantly changing interdependent relationship and volatility transmission of different stock markets. Researchers found that any financial crisis become contagious and effectiveness of portfolio diversification evaporates at a time when it is needed most. Mun (2005) documented that the contagious crisis make investment environment more difficult for a diversified investors because changing correlation trends and uncertainty in financial environment make it difficult to select optimal investment strategy.

Besides that, authors claimed that returns of international diversification are statistically and economically insignificant than that of domestic diversification (Errunza et al., 1999) exhibited that home-biased US investors whose portfolios consisted of equity assets and traded on US stock exchanges may exhaust cross-border diversification benefits. (Cavaglia et al., 2000) found that from 1997, opportunities in industrial inclined returns have overtaken countries inclined returns. (Ewing et al., 2003) studied that investors are interested in the performance of individual stocks as well as in the performance of difference market indices. Poshakwale (2001) has mentioned that previous findings on emerging markets have shown that these markets have complex mechanism and they have been influenced by several factors which in return help the researchers and investors to understand those factors that influence the returns and make them volatile in these stock markets. (Buguk \& Brorsen, 2003) stated that researchers used frequently stock market indices to study the market efficiency and stock performances of emerging financial markets.

(Arbela et al., 2001) examined that high correlation among the central sectors of a stock market explained the weak form efficient market hypothesis. Ewing (2003) examined the sectoral interdependence of five sectors of S\&P 500 and found the strong interrelationship among sectors. Karim (2005) inspected the interdependence relationship of five important sectors in Malaysia stock market and found that the sectors share a causality relationship in short run but this relationship tend to disappear in financial crisis due to the interference of players in the financial sector. Similarly (Wang et al., 2005) studied the constantly changing sectoral interdependence relationship in Chinese stock markets and they found a strong interdependency among sectors. (Al-Fayoumi et al., 2009) examined the daily returns of Amman stock exchange and, after running co-integration and granger causality test, they found interdependence among sectors. They found bidirectional relationship among sectors with the exception of services sectors which led them to report that services sector offers attractive diversification opportunity as it is not linked to other sectors.

(Constantinou et al., 2008) studied the stock market of Cyprus and their results were different as above mentioned. They found that there was no evidence of co-integration in most of bivariate cases in long run and no active sectoral interdependence relationship in short run. Therefore, Cyprus stock market is good for diversification in short run as well as in long run. (Noor et al., 2014) examined Indian stock market to inspect the short run and long run relationship among its different sectors. They gathered the daily share prices of 9 indices listed in BSE from January, 2001 to May, 2013. In order to capture the interdependence among sectors, author's employed co-integration test and granger causality test. They found no co-integration evidence in all sector of BSE except Bankex-IT and Consumer Durables-Realty. They claimed that the above finding means that investors BSE can benefit from portfolio diversification because there is no co- 


\section{The International Journal}

ENTREPRENEURSHIP AND SUSTAINABILITY ISSUES

ISSN 2345-0282 (online) http://jssidoi.org/jesi/

2018 Volume 5 Number 3 (March)

http://doi.org/10.9770/jesi.2018.5.3(8)

integration exists among majority of the sectors. While, the results of granger causality tests, suggest that short term relationship among sectors are limited.

Ahmed (2011) examined the co-movements, causality and sectoral interdependence of in long run and short run among sectors of Egyptians stock market. In author's view point researchers and professionals are more intrigued to explore the integration of capital markets due to the changing dynamics of global economic environment. One of the important reasons of investigating the amalgamation of financial markets and stock markets is to accept the benefits and limitations of diversification in the portfolios. Author further discussed that interdependence of economies has grown stronger due to number of factors over the past three decades. Disassembling of legal embargoes, financial liberalization of economies, increase in the business of multinationals and swift progress in communication infrastructure has deepened the level of interdependence which led to limitation of portfolio diversification. When there is high uncertainty in financial and economic environment across the globe, industry diversified portfolios become more important than cross border portfolios in order to earn expected return keeping regard for the risk.

Narayan et al., (2004) documented that long term periods have less capability to absorb quick information transmission among sectors of an Athens stock market in short run and can completely ignore the transient interactions which only last for few days, therefore, high frequency data is preferred over low frequency data. The author employed unit root tests, Johansen's multivariate co-integration analysis, and Granger's causality test to achieve the objectives of the study. The author concludes that different sectors in a stock market with in a particular economy share a lesser or greater extent to long run equilibrium. This is one the reasons that these sectors move on the similar track in the long run. (Patra \& Poshakwale, 2008) gave evidence that Athens stock exchange is informationally inefficient for instance (Kavussanos \& Dockery, 2001) found that Athens stock market is inefficient by using multivariate generalization regressions. While other researchers like (Siourounis, 2002; Niarchos \& Alexakis, 2003; Panagiotidis, 2005) applied GARCH models to examine the weak form efficient market hypothesis and found that ASE is not weakly efficient.

Patra \& Poshakwale examined the sectoral interdependence in Athens stock market. The main purpose of that study was to find the empirical evidence on short run and long run relationship in major sectors of ASE. The authors explored whether the sectors behave same direction or not and if they share any influential relationship.

They also determined the direction of causality and its consistence over time. This study covered all 18 sectors in ASE but only 6 sectors capitalized $62 \%$ of capitalization, by examined only these 6 sectors for sectoral interdependence might provide good understanding about the behavior and efficiency of Greek stock market. They obtained the daily share prices of 6 sectors from the period of January, 1996 to December, 2003 with 2088 observations. These sectors belongs to Banking, Construction, Industrial, Insurance, Investment and Holding. These sectors dominated heavily when it comes to capitalization and trading ASE. In author's view, in 2003 Banking, Construction and Industry sectors captured 54\% of market capitalization. Apart from using descriptive statistics and co-integration test, they also used variance decomposition tests. The authors found that they did not find any relationship among sectors in the long run but there was a short run relationship. They found that the Banking sector shared a strong relationship with other sectors in the short run and this sector intensely affected other sectors in terms of volatility and returns. They also carried out variance decomposition analysis and found that mostly variance of returns of a particular sector was influenced by that sector's returns but still banking sector was able to explain $25 \%$ and $15 \%$ of construction and insurance variance and industrial, investment and holding variance respectively.

Rahim \& Masih (2016) documented that Shariah (Islamic) investors of Malaysia can obtain handsome rewards by diversifying their portfolios with the Shariah indices of Malaysia's trading partners. The trading partners they included were China, Japan, Singapore, Thailand and United States of America. Prior studies did discuss the interconnection between Malaysian stock market and its trading partners but they ignored time-varying correlations and several and different time horizons. They found that Shariah investors at Malaysian stock market did not gain any diversification benefits when it comes to integral trading partners like China and Singapore but they did get little gain while trading with Japan and Thailand. Bouri et al., (2017) studied the co-integration and nonlinear causality among different sectors of 


\section{The International Journal \\ ENTREPRENEURSHIP AND SUSTAINABILITY ISSUES}

ISSN 2345-0282 (online) http://jssidoi.org/jesi/

2018 Volume 5 Number 3 (March)

http://doi.org/10.9770/jesi.2018.5.3(8)

Indian market. The sectors were gold, oil and stock market. They were of the view that the biggest imports of India are gold and oil and their prices effect the domestic prices of commodities and stock market thus affecting the inflation. They found that there exists a co-integration and nonlinear positive relationship among gold, oil and stock market of India. They also found a bi directional relationship between oil and gold.

Billio et al., (2016) studied the effectiveness of integration measures of portfolio diversification. They compare several measures of financial integration processes. They cluster their sample in developed market equity indices, emerging market indices and developed and emerging market indices. The obtained the monthly equity data and found that all the measures were resulting in similar long run integration pattern. Based on their findings, they termed standard correlations as a good measure to explain variations in diversification benefits. Nitoi et al., (2016) studied the Central and Eastern European countries or CEE for financial convergence. The covered the time period of financial and sovereign debt crisis i.e. 2007 to 2014. They found no evidence of homogenous convergence among the financial markets of CEE countries. They also found that the differences among stock markets of CEE countries have been increased greatly due particularly post financial and sovereign debt crisis but they suggested that structural reforms are needed for bringing in greater financial convergence among CEE countries. Alam et al., (2016) measure the sectoral efficiency of Islamic indices. They took the data of 10 global indices for both Islamic and conventional over a period of 18 years which started from January, 1996 to December, 2014. They further categorize that data into four sub-time periods.

To measure the sectoral efficiency of sampled indices author's employed multifractal de-trended fluctuation analysis. They found the same pattern of efficiency in conventional and Islamic indices for a short horizon time period but Islamic indices showed higher efficiency in the last decade. Kim \& Sun (2017) studied the dynamic conditional correlations between Chinese sector and S \& P 500 index for a period of 2006 to 2014. They found that correlations among the stocks are varying significantly across sectors and over time. They wrote that fruitful investment opportunities in a specific sector arise and are particularly associated with the magnitude of dynamic conditional correlations. Shahzad et al., (2017) examine the risk spillovers and dependence structure among five Islamic stock indices and oil. They studied the downside and upside of risk spillovers and these indices were the Islamic Market World index, Islamic indices of USA, UK, Japan and the Islamic Financials sector index. The authors termed these indices as extremely important. These indices and oil sector are particularly attractive to faith oriented investors. They find that the relationship between oil and Islamic stock indices is based on the time varying lower tails. They also found that there is a risk spillovers effect going on from oil to Islamic stock indices and it was asymmetric. Similarly, risk spillovers were studied in terms of upside and downside of risk.

Bundoo (2017) studied the integration of stock markets of Southern African Development Community or SADC. In this study, the author examined the beta and sigma convergence and applied co-integration to examine the integration of South African stock markets. The author found no co-integration when US stock index was used as benchmark but a greater cointegration was identified when SSA index was used. The author recommended that SADC stock markets should look for more integration with each other to have stable portfolios instead of volatile portfolios. The SADC should also attract foreign direct investment which is essential for stronger stock markets. Chiang and Chen (2016) reviewed the conditional correlations between Chinese stock market and international stock markets. They found that the existence of correlations among stock returns of several stock markets. The correlation was time varying. They also reported that dynamic correlations were tied to the geographical location.

\section{Research Methodology}

\subsection{Data Collection}

This study employed daily closing index of following sectors from Colombo Stock Exchange during the period from January 2003 to August 2016. Bank Finance And Insurance, Beverage Food And Tobacco, Construction And Engineering, Chemicals And Pharmaceuticals, Diversified Holdings, Footwear And Textile, Hotels And Travels, Health Care, Investment Trusts, Information Technology, Land And Property, Manufacturing, Motors, Oil Palms, Power \& Energy, Plantations, Stores Supplies, Services, Telecommunications, Trading; All indices are considered as their local currency and gathered by official web. The returns of these indices have been calculated using following formula (1): 


\section{Returns $=\underline{\text { Index }_{t}-\text { Index }_{t-1}} X 100$ \\ Index $_{t-1}$}

Where:

$$
\text { Index }{ }_{\mathrm{t}}=\text { Closing index, } \quad \text { Index } \mathrm{t}_{\mathrm{t}-1}=\text { Opening index }
$$

For running co-integration, the time series must be stationary at same order. Dickey-Fuller test is applied to determine the stationarity. Johansen's co-integration Test is used to determine long run relationship among various sectors of CSE. The test uses Eigen value or trace statistics. In order to apply Johansen's Co-integration Test, a suitable lag length is selected using VAR based on Akaike Information Criteria (AIC). Granger causality test is employed to determine which sectors cause the movement in index of other sectors. The integration among the sectors can be uni-directional or bi-directional.

\section{Empirical Results}

\subsection{Descriptive Statistics}

Table 1 presents the descriptive statistics of the returns of all listed and studied indexes in Colombo Stock Exchange. In descriptive summary statistics Motors and Oil palms shows highest returns with the value of 0.1175 and 0.1158 while the value of standard deviation is 2.0748 and 3.2693 respectively. Whereas, Telecommunications has the lowest mean returns with the value of 0.0211 while the standard deviation is 1.6497 . Info technology is the most volatile sector having highest standard deviation while Beverages Food Tobacco sector shows the least volatility with lowest standard deviation (Table 1).

Table 1. Descriptive Statistics

\begin{tabular}{lcccc}
\hline Variable & Mean & Std. Dev. & Min & Max \\
\hline INVESTMENTTRUST & 0.0779 & 2.5083 & -26.9359 & 41.9724 \\
LANDPROPERTY & 0.0642 & 1.9927 & -13.3261 & 20.1230 \\
MANUFACTURING & 0.0762 & 1.7608 & -37.7494 & 60.2028 \\
MOTORS & 0.1175 & 2.0748 & -14.9580 & 49.9142 \\
OIL PALMS & 0.1158 & 3.2693 & -32.5968 & 98.8543 \\
PLANTATIONS & 0.0499 & 1.7402 & -14.2950 & 13.4506 \\
POWERENERGY & 0.0337 & 2.0229 & -13.0936 & 59.5500 \\
SERVICES & 0.0691 & 2.2888 & -15.3613 & 34.9052 \\
STORESSUPPLIES & 0.0781 & 2.5107 & -27.2190 & 24.3749 \\
BANKSFINANCEINS & 0.0598 & 1.1445 & -11.6956 & 10.0886 \\
BEVERAGESFOODTOBACCO & 0.0914 & 1.1432 & -10.5224 & 9.3555 \\
CHEMICALPHARMACEUTIC & 0.0615 & 1.5638 & -13.4143 & 13.5518 \\
CONSTRUCTIONENG & 0.0908 & 2.0548 & -13.2766 & 17.4771 \\
DIVERSHOLDINGS & 0.0561 & 1.2994 & -14.5574 & 19.6979 \\
FOOTWEARTEXTILES & 0.0624 & 2.3087 & -17.0271 & 43.8563 \\
HEALTHCARE & 0.0909 & 1.8486 & -11.4769 & 39.4484 \\
HOTELSTRAVELS & 0.0528 & 1.4554 & -11.8181 & 20.5343 \\
INFOTECHNOLOGY & 0.0790 & 4.0400 & -28.5837 & 75.0075 \\
TELECOMUNICATION & 0.0211 & 1.6497 & -14.8148 & 19.8129 \\
TRADING & 0.0980 & 2.0102 & -19.5588 & 24.3003 \\
\hline
\end{tabular}


The International Journal
ENTREPRENEURSHIP AND SUSTAINABILITY ISSUES

ISSN 2345-0282 (online) http://jssidoi.org/jesi/

2018 Volume 5 Number 3 (March)

http://doi.org/10.9770/jesi.2018.5.3(8)

\subsection{Correlation Matrix}

Table-2 shows the correlation matrix of sample indices returns of CSE. The correlation among most of these sectors is low. However, the correlation between Land Property and Bank Finance Insurance, Chemical Pharmaceuticals and Bank Finance Insurance, Diverse Holdings and Bank Finance Insurance, Hotel Travels and Bank Finance Insurance, Bank Finance Insurance and Telecommunication, Bank Finance Insurance and Beverages Food Tobacco, Diverse Holdings and Hotel Travels are high. Correlation matrix consists of two tables for decent presentation (Table 2a and Table 2b).

Table 2a. Correlation Matrix

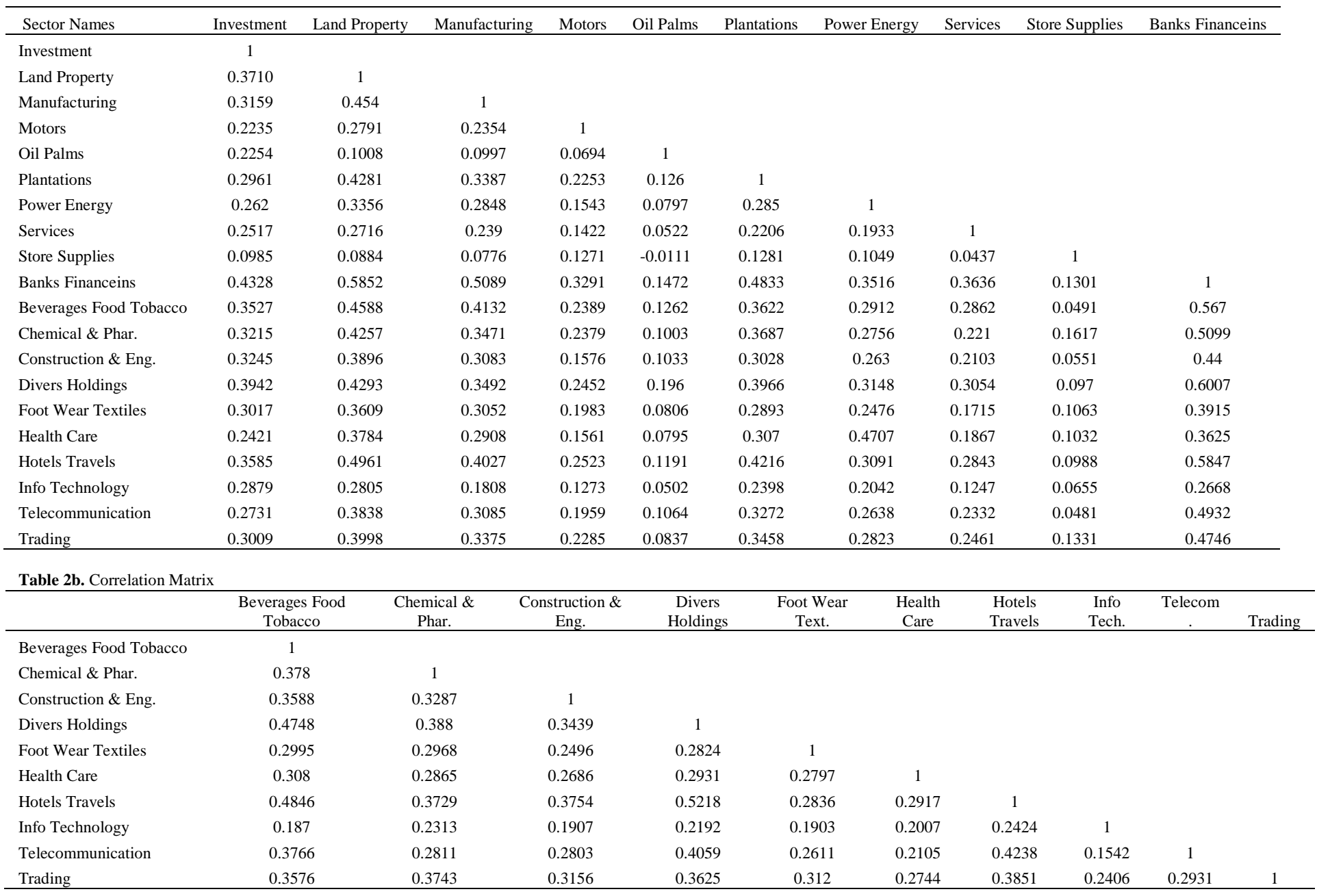

\subsection{Unit Root Test}

The correlation matrix only shows the relationship strength among indices rather to measure the long run relationship among the sector indices. To find the long run relationship among indices applied co-integration test. One of the assumptions of co-integration test is that the time series is stationary. Results of the Dickey Fuller Test for stationarity found that seven sectors are stationary at Level 0 and thirteen sectors are stationary at Level-1. We have selected those thirteen sectors that are stationary at Level 1 (Table $3 a$ and Table $3 b$ ). 
Table 3a. Unit Root Test at Level 0

\begin{tabular}{lcccc}
\hline \multirow{2}{*}{ Sector } & \multirow{2}{*}{ 1\% Critical Value } & \multicolumn{2}{c}{ Level 0 } & \multirow{2}{*}{ Remarks } \\
\cline { 3 - 4 } & & t-stat & Prob. & \\
\hline Footwear And Textile & -3.430 & -3.113 & 0.026 & stationary \\
Health Care & -3.430 & -7.841 & 0.000 & stationary \\
Investment Trusts & -3.430 & -3.388 & 0.011 & stationary \\
Manufacturing & -3.430 & -19.240 & 0.000 & Stationary \\
Power \& Energy & -3.430 & -20.604 & 0.000 & Stationary \\
Plantations & -3.430 & -23.035 & 0.000 & Stationary \\
Stores Supplies & -3.430 & -3.307 & 0.015 & Stationary \\
\hline
\end{tabular}

Table 3 b. Unit Root Test at Level 0 and Level 1

\begin{tabular}{|c|c|c|c|c|c|c|c|}
\hline \multirow[t]{2}{*}{ Sectors } & \multirow[t]{2}{*}{$1 \%$ Critical Value } & \multicolumn{2}{|c|}{ Level 0} & \multirow[t]{2}{*}{ Remarks } & \multicolumn{2}{|c|}{ Level 1} & \multirow[t]{2}{*}{ Remarks } \\
\hline & & t-stat & Prob. & & t-stat & Prob. & \\
\hline Bank Finance And Insurance & -3.430 & -0.522 & 0.888 & not stationary & -47.957 & 0.0000 & stationary \\
\hline Beverage Food And Tobacco & -3.430 & 0.332 & 0.979 & not stationary & -55.567 & 0.0000 & stationary \\
\hline Construction And Engineering & -3.430 & -2.506 & 0.114 & not stationary & -85.005 & 0.0000 & stationary \\
\hline Chemicals And Pharmaceuticals & -3.430 & -1.364 & 0.599 & not stationary & -59.870 & 0.0000 & stationary \\
\hline Diversified Holdings & -3.430 & -2.109 & 0.241 & not stationary & -82.360 & 0.0000 & stationary \\
\hline Hotels And Travels & -3.430 & -2.571 & 0.099 & not stationary & -92.233 & 0.0000 & stationary \\
\hline Information Technology & -3.430 & -2.367 & 0.151 & not stationary & -54.896 & 0.000 & stationary \\
\hline Land And Property & -3.430 & -1.440 & 0.563 & not stationary & -58.023 & 0.000 & stationary \\
\hline Motors & -3.430 & -1.178 & 0.683 & not stationary & -57.286 & 0.000 & stationary \\
\hline Oil Palms & -3.430 & -1.430 & 0.568 & not stationary & -56.001 & 0.000 & stationary \\
\hline Services & -3.430 & -1.483 & 0.542 & not stationary & -61.930 & 0.000 & stationary \\
\hline Telecommunications & -3.430 & -1.823 & 0.369 & not stationary & -57.173 & 0.000 & stationary \\
\hline Trading & -3.430 & -0.949 & 0.771 & not stationary & -56.457 & 0.000 & stationary \\
\hline
\end{tabular}

\subsection{VAR Lag Length Selection}

Before moving towards co-integration and Granger Causality test, it is important to determine the lag length selection. The lag length is determined based on tests of $\mathrm{LR}=$ Sequential modified LR test statistic, FPE= Final prediction error, $\mathrm{AIC}=$ Akaike information criterion, SBIC =Schwarz Bayesian information criterion and HQIC $=$ Hannan-Quinn information criterion. The results of the lag length selection criteria based on the above mentioned test suggest that lag four is suitable for measure the integration and causality (Table 4). 
Table 4. VAR Lag length Selection Criteria

\begin{tabular}{ccccccccc}
\hline lag & LL & LR & df & P & FPE & AIC & HQIC & SBIC \\
\hline 0 & -354481 & & & & $2.10 \mathrm{E}+75$ & 213.166 & 213.175 & 213.192 \\
1 & -259706 & $1.90 \mathrm{E}+05$ & 196 & 0 & $4.20 \mathrm{E}+50$ & 156.294 & 156.432 & $156.679^{*}$ \\
2 & -259149 & 1114.5 & 196 & 0 & $3.40 \mathrm{E}+50$ & 156.076 & 156.343 & 156.822 \\
3 & -258699 & 900.73 & 196 & 0 & $2.90 \mathrm{E}+50$ & 155.923 & $156.319^{*}$ & 157.029 \\
4 & -258426 & $545.89^{*}$ & 196 & 0 & $2.8 \mathrm{e}+50^{*}$ & $155.877^{*}$ & 156.402 & 157.343 \\
\hline
\end{tabular}

\subsection{Multivariate Johansen's Co-integration Test}

The Johansen's multivariate co-integration test suggests the number of co-integrating sectors. However, it does not shows which sector is co-integrated with other sector. To measure the co-integration with one sector to others, study applied Pairwise co-integration (Table 5).

Table 5. Multivariate Johansen's Co-integration Tests

\begin{tabular}{cccccc}
\hline Maximum Rank & Parms & LL & Eigenvalue & Trace Statistics & 5\% Critical Value \\
\hline 0 & 602 & -258771 &. & $690.2177 *$ &. \\
1 & 629 & -258682 & 0.05184 & 513.1745 &. \\
2 & 654 & -258622 & 0.03552 & 392.8739 &. \\
3 & 677 & -258571 & 0.03037 & 290.298 & 277.71 \\
4 & 698 & -258540 & 0.01827 & 228.9845 & 233.13 \\
5 & 717 & -258515 & 0.01502 & 178.6494 & 192.89 \\
6 & 734 & -258493 & 0.01298 & 135.1811 & 156 \\
7 & 749 & -258476 & 0.01053 & 99.9854 & 124.24 \\
8 & 762 & -258459 & 0.00997 & 66.6599 & 94.15 \\
9 & 773 & -258448 & 0.00699 & 43.3416 & 68.52 \\
10 & 782 & -258439 & 0.00534 & 25.5358 & 47.21 \\
11 & 789 & -258432 & 0.00378 & 12.9516 & 29.68 \\
12 & 794 & -258428 & 0.00257 & 4.3948 & 15.41 \\
13 & 797 & -258426 & 0.00122 & 0.323 & 3.76 \\
14 & 798 & -258426 & 0.0001 & & \\
Note: *indicates co integrated equations & & & &
\end{tabular}

\subsection{Pair Wise Co-integration Test}

Table- 6 presents the pair wise co-integration of a selected Sector with all other sectors of both groups. The decision is made on the basis of trace statistics with 5\% critical value of 15.41. The value of trace statistic less than 15.41 shows there is no co-integration between selected sectors. The results of Pairwise co-integration reveal that there are several sectors which are not integrated with each other and provide diversification opportunity to investors. Bank Finance and Insurance sector is not integrated with chemicals pharmaceuticals, info technology, land property, motors, oil palms, services, telecommunication, and trading. Beverages Food and Tobacco sector is least integrated and provides good diversification opportunity with all other sectors whereas construction engineering is not integrated with info technology, land property, motors, oil palms, services, telecommunication and trading. Chemical pharmaceuticals is only integrated with diverse holdings, hotel travels, motors and trading whereas diverse holdings and hotel travels are integrated with most other sectors and do not provide opportunity of diversification. However, info technology, land property, motors, oil palms, 
services, telecommunication and trading are not integrated with most other sectors and provide good diversification opportunities (Table 6, Table 7).

Table 6. Pair wise Co-integration

\begin{tabular}{|c|c|c|c|c|c|c|c|c|c|c|c|c|c|}
\hline & $\begin{array}{c}\text { Banks } \\
\text { Financeins }\end{array}$ & $\begin{array}{c}\text { Beverages } \\
\text { Food } \\
\text { Tobacco } \\
\end{array}$ & $\begin{array}{l}\text { Construction } \\
\text { \& Eng. }\end{array}$ & $\begin{array}{l}\text { Chemical } \\
\text { \& Phar. }\end{array}$ & $\begin{array}{l}\text { Divers } \\
\text { Holdings }\end{array}$ & $\begin{array}{l}\text { Hotels } \\
\text { Travels }\end{array}$ & $\begin{array}{l}\text { Info } \\
\text { Tech. }\end{array}$ & $\begin{array}{c}\text { Land } \\
\text { Property }\end{array}$ & Motors & $\begin{array}{c}\text { Oil } \\
\text { Palms }\end{array}$ & Services & Telecom. & Trading \\
\hline \multicolumn{14}{|l|}{ Banks Financeins } \\
\hline $\begin{array}{l}\text { Beverages } \\
\text { Food Tobacco }\end{array}$ & $2.6455^{*}$ & & & & & & & & & & & & \\
\hline Construction \& Eng. & 18.1745 & $10.416^{*}$ & & & & & & & & & & & \\
\hline Chemical \& Phar. & $3.6825^{*}$ & $3.9554 *$ & 29.2934 & & & & & & & & & & \\
\hline Divers Holdings & 22.3328 & $10.143^{*}$ & 41.7803 & 22.2889 & & & & & & & & & \\
\hline Hotels Travels & 23.9819 & $10.817 *$ & 21.4801 & 45.5335 & 76.0033 & & & & & & & & \\
\hline Info Tech. & $6.8253^{*}$ & $7.4121 *$ & $10.648^{*}$ & $10.031 *$ & $9.3326^{*}$ & $11.850^{*}$ & & & & & & & \\
\hline Land Property & $14.7720 *$ & $13.115^{*}$ & $10.510^{*}$ & $6.4730 *$ & $14.904^{*}$ & $10.630^{*}$ & $8.0899^{*}$ & & & & & & \\
\hline Motors & $5.4468^{*}$ & $2.6513^{*}$ & 26.889 & 41.0661 & 26.8389 & 42.3498 & $10.536^{*}$ & $7.217^{*}$ & & & & & \\
\hline Oil Palms & $12.1673^{*}$ & $4.3802 *$ & 24.3602 & 23.4971 & 46.2601 & 31.7013 & $15.070^{*}$ & 10.620 & 24.961 & & & & \\
\hline Services & $13.0295^{*}$ & $6.1753^{*}$ & 27.683 & $14.196^{*}$ & 84.5886 & 39.1958 & $8.5894^{*}$ & $11.415^{*}$ & 22.479 & 35.793 & & & \\
\hline Telecom. & $3.7452 *$ & $3.9565^{*}$ & $6.8338 *$ & $5.3055^{*}$ & $6.1900^{*}$ & $8.5482 *$ & $9.6290^{*}$ & $5.852 *$ & $5.052 *$ & $5.813 *$ & $5.4748 *$ & & \\
\hline Trading & $5.1552 *$ & $2.4805^{*}$ & 29.5312 & 26.6565 & 37.5094 & 47.4714 & $8.3071^{*}$ & $6.801 *$ & 36.825 & 25.772 & 24.4898 & $4.498^{*}$ & \\
\hline
\end{tabular}

Table 7. Granger Causality Test-Excluded Sectors

\begin{tabular}{|c|c|c|c|c|c|c|c|c|c|c|c|c|c|}
\hline & $\begin{array}{c}\text { Banks } \\
\text { Financeins }\end{array}$ & $\begin{array}{c}\text { Beverages } \\
\text { Food } \\
\text { Tobacco } \\
\end{array}$ & $\begin{array}{l}\text { Construction } \\
\text { \& Eng. }\end{array}$ & $\begin{array}{l}\text { Chemical } \\
\text { \& Phar. }\end{array}$ & $\begin{array}{l}\text { Divers } \\
\text { Holdings }\end{array}$ & $\begin{array}{c}\text { Hotels } \\
\text { Travels }\end{array}$ & $\begin{array}{l}\text { Info } \\
\text { Tech. }\end{array}$ & $\begin{array}{c}\text { Land } \\
\text { Property }\end{array}$ & Motors & $\begin{array}{c}\text { Oil } \\
\text { Palms }\end{array}$ & Services & Telecom. & Trading \\
\hline Banks Financeins & & 1.8713 & 6.7503 & $10.082 *$ & 7.1474 & 7.1667 & 7.8897 & 1.3447 & 4.2301 & 0.3912 & $12.836^{*}$ & 4.6234 & $19.0^{*}$ \\
\hline Construction \& Eng. & 5.1304 & 0.41958 & & $73.736^{*}$ & $16.085^{*}$ & $14.757 *$ & 1.3488 & 8.5622 & 4.4256 & $17.21^{*}$ & 2.5654 & $12.35^{*}$ & 6.564 \\
\hline Chemical \& Phar. & $11.206^{*}$ & 2.1653 & $10.94 *$ & & 4.8245 & 3.8688 & 7.0903 & 5.9149 & 7.0766 & $52.80 *$ & $18.396^{*}$ & 8.3155 & 1.092 \\
\hline Divers Holdings & 2.086 & $10.747 *$ & $63.37 *$ & 5.5293 & & $98.462 *$ & 3.4197 & 4.8801 & 2.0996 & $9.065^{*}$ & $10.549 *$ & 5.295 & 2.755 \\
\hline Info Tech. & 3.5182 & 3.982 & 6.3641 & $16.277^{*}$ & 2.1688 & 8.5466 & & $9.61 *$ & $18.13^{*}$ & $33.18^{*}$ & 7.136 & 4.0084 & 2.173 \\
\hline Land Property & 3.9658 & $10.968 *$ & $14.25^{*}$ & $10.24 *$ & $35.252 *$ & $31.135 *$ & 4.1294 & & $10.18^{*}$ & 1.8049 & 7.7296 & 4.7106 & 3.271 \\
\hline Motors & $19.58 *$ & 0.62725 & 3.3922 & $20.446^{*}$ & 4.2311 & 5.5337 & $9.5072 *$ & 5.33 & & $9.09 *$ & $16.999 *$ & 8.1693 & $23.1 *$ \\
\hline Oil Palms & 6.0819 & 1.1793 & $13.05^{*}$ & 1.6737 & $39.671 *$ & $20.651 *$ & 3.4598 & 4.7053 & 7.8131 & & $10.423 *$ & 1.4318 & 9.057 \\
\hline Services & $14.489 *$ & 8.3176 & 6.6591 & $19.942 *$ & 2.7701 & 8.6613 & $17.75^{*}$ & 6.1482 & 8.7224 & 6.1517 & & 2.1734 & 7.632 \\
\hline Telecom. & 5.3264 & 3.0561 & $28.97 *$ & 2.5769 & $46.42 *$ & $48.143^{*}$ & 8.2943 & 4.1737 & 1.7062 & 6.554 & $12.458 *$ & & 5.536 \\
\hline
\end{tabular}

Note: *indicates significant at $5 \%$ and excluded sector causes equation sector

\subsection{Granger Causality Test}

The results of Granger Causality test show that Hotel Travels, Land Property and Trading cause most of the others sectors. However, Bank Finance Insurance, Beverage Food Tobacco and Chemicals Pharmaceuticals are the least caused sectors. The results also indicates that bi-directional causality exists among Chemicals Pharmaceuticals-Bank Finance Insurance, Services-Bank Finance Insurance, Trading- Bank Finance Insurance, Diverse holdings- Beverage Food Tobacco, Chemicals Pharmaceuticals -Construction, Diverse holdings-Construction, Oil palms-Constructions, TelecommunicationConstructions and Services- Chemicals Pharmaceuticals. The results are of vital importance for an investor who wants to diversify his portfolio within a Sri-Lankan stock market. Bank Finance Insurance, Beverage Food Tobacco and Chemicals Pharmaceuticals are the sectors which are least caused by other section and may serve as important part of an investor's portfolio. 


\section{Conclusion}

This study examines the integration among sectors of Colombo Stock Exchange during the period from 1-12-2003 to 318-2016. Colombo Stock Exchange comprises of 20 sectors. Results of unit root test showes, seven of these sectors were found to be stationary at level 0 and thirteen sectors were stationary at Level 1 . These thirteen sectors were tested for cointegration. The results of the study revealed that Colombo Stock Exchange provides good diversification opportunity to individual or group investors across sectors at natively. The results of Pairwise Johansen's Co-integration test shows that Info technology, Land Property, Motors, Oil palms, Services, Telecommunication and Trading sectors provide excellent diversification opportunity. The results of Granger Causality tests extents that Manufacturing, Store Supplies, Hotel Travels, Land Property and Trading are the sectors which cause other sectors. Plantations, Bank Finance Insurance, Beverage Food Tobacco and Chemicals Pharmaceuticals are the least caused sectors.

From an investor's view point, the findings are helpful in forming a well-diversified portfolio by selecting stocks from those sectors which are not integrated with other sectors and minimize the unsystematic risk through diversification. The results of the study are particularly encouraging for those investors who want to diversify their portfolios domestically especially those investors who do not have access to international markets. One of the limitations of the study is that it ignores the impact of seven sectors which were found to be stationary at level 0 , while running co-integration. Thus, the impact of these sectors while forming a diversified portfolio is ignored. For a future researcher, it is suggested to seek diversification opportunities among those sectors of CSE also that are stationary at Level 0.

\section{References}

Alam, N.; Arshad, S; Rizvi, S.A.R. (2016). Do Islamic stock indices perform better than conventional counterparts? An empirical investigation of sectoral efficiency. Review of Financial Economics, 31(1), 108-114. https://doi.org/10.1016/j.rfe.2016.06.003

Ahmed, W. M. (2011). Comovements and causality of sector price indices: Evidence of the Egyptian Stock Exchange. International Journal of Business and Emerging Markets, 4(3), 200-222. https://doi.org/10.1504/IJBEM.2012.047779

Al-Fayoumi, N. A.; Khamees, B. A.; Al-Thuneibat, A. A. (2009). Information transmission among stock return indexes: evidence from the Jordanian stock market. International Research Journal of Finance and Economics, 24, 194-208. http://www.eurojournals.com/finance.htm

Arbeláez, H.; Urrutia, J.; \& Abbas, N. (2001). Short-term and long-term linkages among the Colombian capital market indexes. International Review of Financial Analysis, 10(3), 237-273. https://doi.org/10.1016/S1057-5219(01)00051-5

Arshanapalli, B.; \& Doukas, J. (1993). International stock market linkages: Evidence from the pre-and post-October 1987 period. Journal of Banking \& Finance, 17(1), 193-208. https://doi.org/10.1016/0378-4266(93)90088-U

AuYong, H. H.; Gan, C.; \& Treepongkaruna, S. (2004). Cointegration and causality in the Asian and emerging foreign exchange markets: Evidence from the 1990s financial crises. International Review of Financial Analysis, 13(4), 479-515. https://doi.org/10.1016/j.irfa.2004.02.024

Bouri, E.; Anshul, Jain; P.C. Biswal; David, Roubaud. (2017). Cointegration and nonlinear causality amongst gold, oil, and the Indian stock market: Evidence from implied volatility indices. Resources Policy, 52, 201-206.

https://doi.org/10.1016/j.resourpol.2017.03.003

Bekaert, G.; Harvey, C. R.; \& Lundblad, C. (2005). Does financial liberalization spur growth? Journal of Financial economics, 77(1), 3-55. https://doi.org/10.1016/j.jfineco.2004.05.007

Buguk, C.; \& Brorsen, B. W. (2003). Testing weak-form market efficiency: Evidence from the Istanbul Stock Exchange. International review of financial analysis, 12(5), 579-590. https://doi.org/10.1016/S1057-5219(03)00065-6

Cavaglia, S.; Melas, D. and Tsouderos, G. (2000). Cross industry and cross country international equity diversification. The Journal of Investing, 9(1), 65-71. https://doi.org/10.3905/joi.2000.319401

Chiang, T. C.; Chen, X. (2016). Empirical Analysis of Dynamic Linkages between China and International Stock Markets. Journal of Mathematical Finance, 6(1), 189-212. http://dx.doi.org/10.4236/jmf.2016.61018 


\section{The International Journal}

ENTREPRENEURSHIP AND SUSTAINABILITY ISSUES

ISSN 2345-0282 (online) http://jssidoi.org/jesi/

2018 Volume 5 Number 3 (March)

http://doi.org/10.9770/jesi.2018.5.3(8)

Constantinou, E.; Kazandjian, A.; Kouretas, G.; Tahmazian, V. (2008). Cointegration, causality and domestic portfolio diversification in the Cyprus stock exchange. Journal of Money, Investment and Banking, 4, 26-41. http://economics.soc.uoc.gr/wpa/docs/Causal.pdf

Chung, P. J.; \& Liu, D. J. (1994). Common stochastic trends in Pacific Rim stock markets. The Quarterly Review of Economics and Finance, 34(3), 241-259. https://doi.org/10.1016/1062-9769(94)90026-4

Darbar, S. M.; \& Deb, P. (1997). Co-Movements in International Equity Markets. Journal of Financial Research, $20(3)$, $305-322$. https://doi.org/10.1016/j.intfin.2006.05.001

Errunza, V.; Hogan, K. and Hung, M. W. (1999). Can the gains from international diversification be achieved without trading abroad? Journal of Finance, 54(6), 2075-2107. https://doi.org/10.2469/dig.v30.n4.765

Ewing, B. T.; Forbes, S. M. and Payne, J. E. (2003). The effects of macroeconomic shocks on sector-specific returns. Applied Economics, 35(2), 201207. https://doi.org/10.1080/0003684022000018222

Fernandez-Izquierdo, A.; \& Lafuente, J. A. (2004). International transmission of stock exchange volatility: Empirical evidence from the Asian crisis. Global Finance Journal, 15(2), 125-137. https://doi.org/10.1016/j.gfj.2004.02.002

Grubel, M.; \& Fadner, K. (1971). The interdependence of international equity markets. Journal of Finance, 26(1), 89-94. doi:10.1111/j.1540$\underline{6261.1971 . t b 00591}$

Ghosh, A.; R. Saidi; \& Johnson, K. H. (1999). Who moves the Asia-Pacific stock markets -US or Japan? Empirical evidence based on the theory cointegration. The Financial Review, 34(1), 159-170. doi:10.1111/j.1540-6288.1999.tb00450.x

Glezakos, M.; Merika, A.; \& Kaligosfiris, H. (2007). Interdependence of major world stock exchanges: How is the Athens stock exchange affected. International Research Journal of Finance and Economics, 7(1), 24-39. https://www.researchgate.net/profile/Anna_Merika

Huang, B. N.; Yang, C. W.; \& Hu, J. W. S. (2000). Causality and cointegration of stock markets among the United States, Japan and the South China Growth Triangle. International Review of Financial Analysis, 9(3), 281-297. https://doi.org/10.1016/S1057-5219(00)00031-4

Kavussanos, M. G.; \& Dockery, E. (2001). A multivariate test for stock market efficiency: the case of ASE. Applied Financial Economics, 11(5), 573-579. https://doi.org/10.1080/09603100010013006

Karim, M.Z.A. (2005). Stock Price Integration in the Malaysian Stock Market. Thammasat Economic Journal, 23(3): 123-145. https://www.researchgate.net/profile/Mohd_Zaini_Abd_Karim

Kim, M.H.; Sun, L. (2017). Dynamic conditional correlations between Chinese sector returns and the S\&P 500 index: An interpretation based on investment shocks. International Review of Economics \& Finance, 48, 309-325. https://doi.org/10.1016/j.iref.2016.12.014

Levy, H.; \& Marshall, S. (1970). International diversification of investment portfolios. The American Economic Review, 60(4), 668-675. http://www.jstor.org/stable/1818410

Longin, F.; \& Solnik, B. (1995). Is the correlation in international equity returns constant: 1960-1990? Journal of International Money and Finance, 14(1), 3-26. https://doi.org/10.1016/0261-5606(94)00001-H

Markowitz, H. (1952). Portfolio Selection. Journal of Finance. 7(1), 77-91. doi:10.1111/j.1540-6261.1952.tb01525.x

Masih, A.M.M.; \& Masih, R. (2002). Propagative causal price transmission among international stock markets: Evidence from the pre- and postglobalization period. Global Finance Journal, 13(1), 63-91. https://doi.org/10.1016/S1044-0283(02)00039-X

M, Billio.; M, Donadelli; A, Paradiso; M, Riedel. (2017). Which market integration measure?. Journal of Banking \& Finance, $76,150-174$. https://doi.org/10.1016/j.jbankfin.2016.12.002

Murinde, V.; \& Poshakwale, S. (2001). Volatility in the Emerging Stock Markets in Central and Eastern Europe: Evidence on Croatia, Czech Republic, Hungary, Poland, Russia and Slovakia. European Research Studies, 4(3-4), 73-101. http://www.ersj.eu/repec/ers/papers/01 34 p6.pdf

Mun, C. K. C. (2005). Contagion and impulse response of international stock markets around the 9-11 terrorist attacks. Global Finance Journal, 16(1), 48-68. https://doi.org/10.1016/j.gfj.2005.05.002

Niarchos, N. A.; \& Alexakis, C. A. (2003). Intraday stock price patterns in the Greek stock exchange. Applied Financial Economics, $13(1)$, 13-22. $\underline{\text { https://doi.org/10.1080/09603100110088166 }}$

Niţoi, M.; Pochea, M.M. (2016). Testing financial markets convergence in Central and Eastern Europe: A non-linear single factor model. Economic Systems, 40(2), 323-334. https://doi.org/10.1016/j.ecosys.2016.02.002 


\section{ENTREPRENEURSHIP AND SUSTAINABILITY ISSUES \\ The International Journal}

ISSN 2345-0282 (online) http://jssidoi.org/jesi/

2018 Volume 5 Number 3 (March)

http://doi.org/10.9770/jesi.2018.5.3(8)

Noor, M. A.; \& Khan, M. A. (2014). Co-movement analysis among different sectors of Indian stock market. International Journal of Research, 1(4).540-556. https://edupediapublications.org/journals/index.php/IJR/article/view/91/66

Odier, P. and Solnik, B. (1993). Lessons for international asset allocation. Financial Analysts Journal, 49(2), 63-77. https://doi.org/10.2469/faj.v49.n2.63

Olienyk, J.P.; Schwebach, R.G.; \& Zumwalt, J.K. (2002). The impact of financial crises on international diversification. Global Finance Journal, 13(2): 147-161. https://doi.org/10.1016/S1044-0283(02)00050-9

Patra, T.: \& Poshakwale, S. S. (2008). Long-run and short-run relationship between the main stock indexes: evidence from the Athens stock exchange. Applied Financial Economics, 18(17), 1401-1410. https://doi.org/10.1080/09603100701704314

Panagiotidis, T. (2005). Market capitalization and efficiency. Does it matter? Evidence from the Athens Stock Exchange. Applied Financial Economics, 15(10), 707-713. https://doi.org/10.1080/09603100500107883

Rahim, A. M.; Masih, M. (2016). Portfolio diversification benefits of Islamic investors with their major trading partners: Evidence from Malaysia based on MGARCH-DCC and wavelet approaches. Economic Modelling, 54, 425-438. https://doi.org/10.1016/j.econmod.2015.12.033

Shahzad, S. J. H.; Mensi, W.; Hammoudeh, S.; Rehman, U. M.; Yahyaee, H.K. (2017). Extreme dependence and risk spillovers between oil and Islamic stock markets. Emerging Markets Review, (In Press). https://doi.org/10.1016/j.ememar.2017.10.003

Shamsuddin, A. F.; \& Kim, J. H. (2003). Integration and interdependence of stock and foreign exchange markets: an Australian perspective. Journal of International Financial Markets, Institutions and Money, 13(3), 237-254. https://doi.org/10.1016/S1042-4431(02)00046-X

Soydemir, G. (2000). International transmission mechanism of stock market movements: evidence from emerging equity markets. Journal of Forecasting, 19(3), 149-176. https://doi.org/10.1002/(SICI)1099-131X(200004)19:3<149::AID-FOR735>3.0.CO;2-C

Sheng, H. C.; \& Tu, A. H. (2000). A study of cointegration and variance decomposition among national equity indices before and during the period of the Asian financial crisis. Journal of Multinational Financial Management, 10(3), 345-365. https://doi.org/10.1016/S1042-444X(00)00034-7

Sunil, K. B. (2017). Stock market development and integration in SADC (Southern African Development Community). Review of Development Finance, 7(1), 64-72. https://doi.org/10.1016/j.rdf.2017.01.005

Siourounis, G. D. (2002). Modelling volatility and testing for efficiency in emerging capital markets: the case of the Athens stock exchange. Applied Financial Economics, 12(1), 47-55. https://doi.org/10.1080/09603100110088003

Wang, Z.; Kutan A., and Yang, J. (2005). Information flows within and across sectors in Chinese stock markets. The Quarterly Review of Economics and Finance, 45 (4-5), 767-780. https://doi.org/10.1016/j.qref.2003.08.001 


\section{ENTREPRENEURSHIP AND SUST \\ ISSN 2345-0282 (online) http://jssidoi.org/jesi/ \\ 2018 Volume 5 Number 3 (March) \\ http://doi.org/10.9770/jesi.2018.5.3(8)}

Awais AHMED, MS is a lecturer of finance in the department of Lahore Business School at The University of Lahore. He has more than 4 years of teaching and research experience at the university level. His research interest includes Investment Analysis and portfolio management.

ORCID ID: https://orcid.org/0000-0002-7901-3554

Rizwan ALI, PhD is an assistant professor of finance in the department of Lahore Business School at The University of Lahore. He has more than 7 years of teaching and research experience at the university level. His research interest includes corporate finance, corporate governance, portfolio management and financial integration.

ORCID ID: https://orcid.org/0000-0002-4439-6815

Abdullah EJAZ, PhD is an assistant professor of finance in the department of Lahore Business School at The University of Lahore. He has more than 2 years of teaching and research experience at the university level. His research interest includes moment strategies and portfolio management. ORCID ID: https://orcid.org/0000-0003-4825-7553

M. Ishfaq AHMAD, PhD is an assistant professor of finance in the debarment of Lahore Business School at The University of Lahore. He has more than 8 years of teaching and research experience at the university level. His research interest includes corporate finance, corporate governance and NPL's.

ORCID ID: https://orcid.org/0000-0003-1468-1073

Register for an ORCID ID:

https://orcid.org/register

Copyright (C) 2018 by author(s) and VsI Entrepreneurship and Sustainability Center

This work is licensed under the Creative Commons Attribution International License (CC BY).

http://creativecommons.org/licenses/by/4.0/

(c) (i) Open Access 